\title{
A Conceptual Framework for Describing the Phenomenon of New Venture Creation
}

\author{
WILLIAM B. GARTNER \\ Georgetown University
}

\begin{abstract}
A review of the entrepreneurship literature suggests that differences among entrepreneurs and among their ventures are as great as the variation between entrepreneurs and nonentrepreneurs and between new firms and established firms. A framework for describing new venture creation integrates four major perspectives in entrepreneurship: characteristics of the individual(s) who start the venture, the organization which they create, the environment surrounding the new venture, and the process by which the new venture is started.
\end{abstract}

The major thrust of most entrepreneurship research has been to prove that entrepreneurs are different from nonentrepreneurs (Brockhaus, 1980a, 1980b; Carland, Hoy, Boulton, \& Carland, 1984; Collins \& Moore, 1964; DeCarlo \& Lyons, 1979; Hornaday \& Aboud, 1971; Howell, 1972; Komives, 1972; Litzinger, 1965; McClelland, 1961; McClelland \& Winter, 1969; Palmer, 1971; Schrier, 1975; Shapero, 1975) and that entrepreneurial firms are different from nonentrepreneurial firms (Collins \& Moore, 1970; Cooper, 1979; Smith, 1967; Thorne \& Ball, 1981). The basic assumption underlying this research is that all entrepreneurs and their new ventures are much the same. The present paper suggests that the differences among entrepreneurs and among their ventures are much greater than one might expect; in fact, the diversity may be larger than the differences between entrepreneurs and nonentrepreneurs and between entrepreneurial firms and nonentrepreneurial firms. Once the diversity among entrepreneurs and their ventures is recognized, the necessity for finding a way to classify them becomes apparent. Groups sharing

\footnotetext{
The research leading to this paper was supported in part by a grant from the National Science Foundation and is based on the author's doctoral dissertation. Additional support was provided by the Center for Entrepreneurial Studies, University of Virginia.

Requests for reprints should be sent to William B. Gartner, Center for Entrepreneurship Studies, School of Business Administration, Georgetown University, Washington, D.C. 20057.
}

similar characteristics must exist within the universe of entrepreneurs and their ventures. How are these groups revealed? Many different characteristics have been employed in past research to describe entrepreneurs and their ventures. Do the characteristics themselves fall into groups? In other words, does one subset of characteristics describe a single aspect of new venture creation, such as the environment surrounding the new venture, or the features of the organization that results?

This paper attempts to organize the many variables that have been used in past research to describe entrepreneurs and their ventures into a comprehensive framework. Far from being reductive, this new view of the entrepreneurship literature should provide valuable insights into the process of new venture creation by showing it to be a complex and multidimensional phenomenon. Once a clear retrospective analysis of the literature is provided, future research can proceed on more solid footing. Instead of many different researchers palpating different parts of the elephant and reaching reductive conclusions, at least all will know the name, if not the nature, of the beast with which they are dealing.

Much past research has been unidimensional, focusing on a single aspect of new venture creation, and its main purpose has been to show how entrepreneurs or their firms differ from nonentrepreneurs or nonentrepreneurial firms. (In fact, it might be said that unidimensional research goes 
hand in hand with the attitude that all entrepreneurs and their firms are alike, the task of the unidimensional research being to prove how all things entrepreneurial differ from all things nonentrepreneurial.) It has been consistently pointed out, however, in reviews of literature on entrepreneurs, for example, (Brockhaus, 1982; Glueck \& Mescon, 1980; McCain \& Smith, 1981) that variables that are assumed to differentiate entrepreneurs from nonentrepreneurs (managers, for instance) frequently do not bear up under close scrutiny. Yet the search for these elusive variables continues, and entrepreneurs and prospective entrepreneurs are subjected to batteries of psychological tests in attempts to isolate the single spring that makes them tick differently from others. As with other aspects of new venture creation, attempts are made to isolate key variables that separate entrepreneurial situations from nonentrepreneurial ones. Pennings (1980, 1982a, 1982b) has explored environments that support new venture creation; Van de Ven (1980) and Kimberly (1979) have focused on the process of venture creation.

This search for key variables is a motivation for research only if the task of entrepreneurial research is taken to be the distinction of entrepreneurs and things entrepreneurial from nonentrepreneurs and nonentrepreneurial situations. If a much different perspective is taken, the perspective that there are many different kinds of entrepreneur and many ways to be one and that the firms they create vary enormously as do the environments they create them in, then the burden shifts. How is each new venture creation different from another? Researchers need to think in terms of a combination of variables that make up each new venture creation (Van de Ven, Hudson, \& Schroeder, 1984). The creation of a new venture is a multidimensional phenomenon; each variable describes only a single dimension of the phenomenon and cannot be taken alone. There is a growing awareness that the process of starting a business is not a single well-worn route marched along again and again by identical entrepreneurs (Hartman, 1983). New venture creation is a complex phenomenon: entrepreneurs and their firms vary widely; the actions they take or do not take and the environments they operate in and respond to are equally diverse - and all these elements form complex and unique combinations in the creation of each new venture. It is not enough for researchers to seek out and focus on some concept of the "average" entrepreneur and the "typical" venture creation. New organizational forms evolve through variation, and this variation in new venture creation needs to be studied (Aldrich, 1979; Hannan \& Freeman, 1977; Pfeffer \& Salancik, 1978; Weick, 1979). This insistence on variation can be seen, for example, in Vesper (1979), who posits 11 different kinds of entrepreneur, and in a recent study by Cooper and Dunkelberg (1981), which reveals that entrepreneurs in certain industries can be very different from those in other industries.

Once the variation and complexity in new venture creation is recognized, it then is necessary to find a framework for systematically discovering and evaluating the similarities and differences among new ventures (McKelvey, 1982). Once it is no longer assumed that all entrepreneurs and their ventures present a homogeneous population, then other homogeneous subsets within the entrepreneurial universe must be sought out in order that entrepreneurial research can produce meaningful results. A primary value of the framework for describing new venture creation presented here is that it provides a systematic means of comparing and contrasting complex ventures; it provides a way to conceptualize variation and complexity.

\section{A Framework for Describing New Venture Creation}

Definitions of key words such as entrepreneur are often various and always a problem in the study of entrepreneurship (Brockhaus, 1980b; Komives, 1969; Long, 1983). Because the entrepreneur is only one dimension of this framework, it seems more important in this paper to define the term "new venture creation." Such a definition can be outlined here with less trepidation, if only because there is less precedent.

New venture creation is the organizing (in the Weickian sense) of new organizations. "To organize is to assemble ongoing interdependent actions into sensible sequences that generate sensible outcomes" (Weick, 1979, p. 3). The definition of new venture creation is synonymous with 
the definition of the new organization developed by the Strategic Planning Institute (1978, p. 1-2):

a new business venture launched as one of the following:

1. an independent entity

2. a new profit center within a company which has other established businesses, or

3. a joint venture which satisfies the following criteria:

1. Its founders must acquire expertise in products, process, market and/or technology.

2. Results are expected beyond the year in which the investment is made.

3. It is considered a new market entrant by its competitors.

4. It is regarded as a new source of supply by its potential customers.

The importance of this definition should not be overlooked, because it recognizes the multidimensional aspects of new venture creation. First, it emphasizes that individuals with expertise are a key element of the new venture. At the same time that it recognizes the new venture as an organizational entity, it stresses that the new venture is not instantaneously produced, but evolves over time (beyond a year). The new venture is seen further within the context of its environment: it is forced to seek out resources, and it competes in the market place. All these aspects of the new venture must be kept in mind if it is to be adequately described and classified.

Figure 1 presents a framework for describing the creation of a new venture across four dimensions: (a) individual(s)-the person(s) involved in starting a new organization; (b) organization--the kind of firm that is started; (c) environment-the situation surrounding and influencing the new organization; and (d) new venture process-the actions undertaken by the individual(s) to start the venture.

Any new venture is a gestalt (Miller, 1981) of variables from the four dimensions. No new ven- ture creation can be comprehensively described, nor can its complexity be adequately accounted for, unless all of its four dimensions are investigated and an attempt is made to discover how variables from each dimension interact with variables from other dimensions.

This framework is the first to combine the four dimensions of venture creation, though other researchers have sought to combine two or more of the dimensions. This "thinking across dimensions" is especially apparent in the work of those theorists and researchers who have developed entrepreneurial classification schemes. Classifications of entrepreneurs themselves are often based on two dimensions: individual characteristics plus new venture process considerations the word often used is "style." Danhoff (1949) based his scheme on the entrepreneur's openness to innovation; Cole (1959) on the sophistication of the entrepreneur's decision making tools; and Dailey (1971) according to bureaucratic or entrepreneurial style. Smith (1967) divided entrepreneurs by a stylistic orientation - craftsman or opportunistic. Filley and Aldag (1980) used management orientation. Vesper $(1979,1980)$ in two similar classifications differentiated among entrepreneurs by the activities involved in business formation and operation, and in another scheme (1980) by competitive strategy. In Cooper (1979) entrepreneurs are linked to particular environments, and, as cited previously, Cooper and Dunkelberg's (1981) study matches different entrepreneurs and their characteristics to the types of firms they are likely to start. In Vesper's (1979) classification the entrepreneur's type of firm is also a factor, as it is in several other classification studies (Braden, 1977; Filley \& Aldag, 1980; Smith, 1967). Recently, Van de Ven et al.'s (1984) empirical study examined educational software firms on the basis of three dimen-

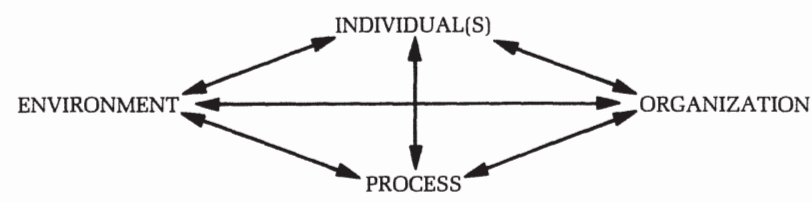

Figure 1. A framework for describing new venture creation. 
sions: entrepreneurial-background characteristics and psychological attributes of the founding entrepreneurs; organizational-planning and organizational activities undertaken before and after company startup; and ecological-support and resources made available to influence the development of the industry. These classification schemes and frameworks are ways of stepping back to get an overall picture, a process like model-building, which involves integration and synthesis.

\section{Individual(s)}

Whether an entrepreneur is viewed as a "captain of industry," a hard-headed risk bearer (Mill, 1848), risk taker (Palmer, 1971) or a "rapacious risk avoider" (Webster, 1976); whether he merely metamorphoses into an entrepreneur at certain moments and is something else the rest of the time (Danhoff, 1949), or whether his need for achievement (McClelland, 1961) and capacity for innovation (Schumpeter, 1934) are always ticking away; whether he is a "displaced person" (Shapero, 1975), something close to a juvenile delinquent (Gould, 1969), or a "man apart” (Liles, 1974) with an absolutely clear-headed (veridical) perception of reality (Schrage, 1965), an aberrant "artist" with an "innate sense of impending change" (Hill, 1982); or whether he is, indeed, that completely political animal, a community builder (Schell \& Davig, 1981), the entrepreneur is overwhelmingly perceived to be different in important ways from the nonentrepreneur, and many researchers have believed these differences to lie in the background and personality of the entrepreneur.

One often pursued avenue has been the attempt to develop a psychological profile of the entrepreneur and to measure such psychological characteristics as need for achievement (DeCarlo \& Lyons, 1979; Hornaday \& Aboud, 1971; McClelland, 1961; McClelland \& Winter, 1969; Schwartz, 1976). However, other researchers have not found need for achievement useful in describing entrepreneurs (Brockhaus, 1980b; Litzinger, 1965; Schrage, 1965); still others have questioned the value and validity of using psychological characteristics of any kind to describe entrepreneurs (Brockhaus, 1982; Glueck \& Mescon, 1980; Jenks, 1965; Kilby, 1971; McCain \& Smith,
1981; Van de Ven, 1980). However, the following psychological characteristics have been used in many studies and may have some validity in differentiating among types of entrepreneurs (Brockhaus, 1982):

1. Need for achievement

2. Locus of control

3. Risk taking propensity

Some researchers have found it fruitful to look at the entrepreneur's background, experience, and attitudes. Some individual characteristics that may be of value in describing entrepreneurs are:

1. Job satisfaction (Collins \& Moore, 1970; Komives, 1972)

2. Previous work experience (Cooper, 1970; Lamont, 1972; Susbauer, 1972)

3. Entrepreneurial parents (Collins \& Moore, 1970; Roberts \& Wainer, 1968; Schrier, 1975; Secrest, 1975; Shapero, 1972; Susbauer, 1972)

4. Age (Komives, 1972; Liles, 1974; Roberts \& Wainer, 1968; Secrest, 1975; Thorne \& Ball, 1981)

5. Education (Brockhaus \& Nord, 1979; Collins \& Moore, 1964; Howell, 1972; Roberts, 1969; Susbauer, 1969)

\section{Process}

In 1949 Danhoff wrote, "Entrepreneurship is an activity or function and not a specific individual or occupation . . . the specific personal entrepreneur is an unrealistic abstraction" (p. 21) Other theorists have pursued this idea of function and have tried to differentiate the entrepreneurial function from other more routine functions such as the managerial function (Baumol, 1968; Cole, 1965; Hartmann, 1959; Leibenstein, 1968; Schumpeter, 1934). This "dynamic" aspect of the entrepreneur has been acknowledged in the work of eight researchers who have enumerated certain actions that an entrepreneur performs in order to create a new venture. Except for Peterson and Berger (1971), who described the entrepreneurial activities of record producers, these studies were theoretical, that is, based on general observation rather than systematic research. The similarities in their views are summarized here; six common behaviors are listed (the order does not imply a sequence of actions):

1. The entrepreneur locates a business opportunity (Cole, 1965; Kilby, 1971; Maidique, 1980; Schumpeter, 1934; Vesper, 1980).

2. The entrepreneur accumulates resources (Cole, 1965; Kilby, 1971; Leibenstein, 1968; Peterson \& Berger, 1971; Schumpeter, 1934; Vesper, 1980). 
3. The entrepreneur markets products and services (Cole, 1965; Kilby, 1971; Leibenstein, 1968; Maidique, 1980; Peterson \& Berger, 1971; Schumpeter, 1934; Vesper, 1980).

4. The entrepreneur produces the product (Kilby, 1971; Maidique, 1980; Peterson \& Berger, 1971; Schumpeter, 1934; Vesper, 1980).

5. The entrepreneur builds an organization (Cole, 1965; Kilby, 1971; Leibenstein, 1968; Schumpeter, 1934).

6. The entrepreneur responds to government and society (Cole, 1965; Kilby, 1971).

\section{Environment}

Much of the current concern (Peters \& Waterman, 1982) over how to design organizations that keep and encourage innovative individuals is an indirect acknowledgment that entrepreneurs do not operate in vacuums - they respond to their environments. The existence of highly supportive regional entrepreneurial environments (Cooper, 1970; Draheim, 1972; Pennings, 1982b; Susbauer, 1972) - including "incubator organizations" - can, from one perspective, be said actually to create entrepreneurs. The idea of "pushes" and "pulls" from the environment has found its way into many studies of entrepreneurship (Shapero \& Sokol, 1982).

In organization theory literature, two different views of the environment have been developed. One perspective, environmental determinism, sees the environment as an outside set of conditions to which the organization must adapt (Aldrich, 1979; Aldrich \& Pfeffer, 1976; Hannan \& Freeman, 1977). The other perspective, strategic choice, sees the environment as a "reality" that organizations create via the selectivity of their own perceptions (Child, 1972; Starbuck, 1976; Weick, 1979). In the entrepreneurship literature, both perspectives on the environment have been taken. In the present paper those characteristics that are viewed as relatively fixed conditions imposed on the new venture from without are called environmental variables. Variables over which the organization has more control (strategic choice variables) are more readily viewed as characteristics of the organization itself and are treated as such.

In an overview of 17 research papers on environmental variables that influenced new venture creation, Bruno and Tyebjee (1982) found 12 factors that they judged stimulated entrepreneurship:
1. Venture capital availability

2. Presence of experienced entrepreneurs

3. Technically skilled labor force

4. Accessibility of suppliers

5. Accessibility of customers or new markets

6. Governmental influences

7. Proximity of universities

8. Availability of land or facilities

9. Accessiblity of transportation

10. Attitude of the area population

11. Availability of supporting services

12. Living conditions

Another study of environmental influences on new venture creation was Pennings' studies of organization birth frequencies (1980, 1982a, $1982 \mathrm{~b})$. Pennings found that organization birth rates were high in areas with: high occupational and industrial differentiation; high percentages of recent immigrants in the population; a large industrial base; larger size urban areas; and availability of financial resources.

Another field of research has taken the deterministic perspective regarding the environment and new ventures: industrial economics. Oliver Williamson (1975) explored the process by which the failure of markets to coordinate efficiently the production and distribution of goods and services often resulted in the start-up of organizations to coordinate the production function through administration. Porter (1980) focused on the competitive environment that confronts firms in a particular industry. Porter's work provides five environmental influences on organizations: barriers to entry, rivalry among existing competitors, pressure from substitute products, bargaining power of buyers, and bargaining power of suppliers.

\section{Organization}

Despite a bold early attempt by Stauss (1944) to direct the focus away from the entrepreneur and toward his created organization (by claiming, somewhat tortuously, that the firm is the entrepreneur), most subsequent studies of new venture creation have neglected to comment on or even communicate certain characteristics of the organizations on which they focused. The assumption behind this seems to derive from two other assumptions: (a) if all entrepreneurs are virtually alike and (b) they all go through the same process to create their ventures, then (c) the organizations they create must, like widgets, not be of any interest in themselves. 
Many research samples in entrepreneurship studies are selected, for example, without regard to type of firm (i.e., manufacturing, service, retail, wholesale). Of the studies that have indicated the type of firm, Smith (1967), Cooper (1970), Collins and Moore (1970), Susbauer (1972), and Braden (1977) studied manufacturing firms, and most focused on high technology manufacturing firms. Litzinger (1965) studied motel firms, and Mescon and Montanari (1981) studied real estate firms. However, researchers in these studies made no attempts to compare the type of firm studied to other types of firm to determine what difference type of firm might make in the process of new venture creation. Cooper and Dunkelberg (1981), Gartner (1982), and Van de Ven et al. (1984) have begun to link type of firm across other dimensions, such as entrepreneurial background and response to environment.

The presence of partners is another firm characteristic suggested by Timmons, Smollen, and Dingee (1977) as a vital factor in starting certain types of firm, and some research has mentioned partners as a characteristic of the firms studied (Cooper, 1970; DeCarlo \& Lyons, 1979).

Strategic choice variables are treated here as characteristics of the organization. Porter (1980) identified three generic competitive strategies that firms may "choose": (a) overall cost leadership, (b) differentiation, and (c) focus. Vesper (1980) identified 14 competitive entry wedges: the new product or service, parallel competition, franchise entry, geographical transfer, supply shortage, tapping unutilized resources, customer contract, becoming a second source, joint ventures, licensing, market relinquishment, sell off of division, favored purchasing by government, and governmental rule changes.

\section{Conclusion}

Listing each variable of new venture creation under the appropriate dimension of the framework illustrates the potential for a high degree of complexity in the interaction of these variables within the multidimensional phenomenon of venture creation (Figure 2).

The four dimensional conceptual framework can be seen as a kaleidoscope, as an instrument through which to view the enormously varying patterns of new venture creation. Past attempts to differentiate the typical entrepreneur and his/ her typical creation from all nonentrepreneurs and all nonnew ventures have, whether intentionally or not, advanced the notion that all entrepreneurs are alike and all new venture creation is the same. However, there clearly is a wide variation in the kinds of new ventures that are started. For example, are there similarities between the creation of a waterbed store by a 20 -year old college student and the creation of a personal computer company by three engineers? Are the differences between them more important than the similarities? What is the value of comparing the creation of a pet store by two unemployed physical therapists to the creation of a 5,000-acre business park by four real estate developers? The goal is not to smooth over any differences that might exist among these new ventures or to throw these very different individuals into the same pot in order to extract the typical qualities of the typical entrepreneur. The goal is to identify the specific variables that describe how each new venture was created, in order that meaningful contrasts and comparisons among new ventures can be made.

First must come careful description with an eye to variation. The search for key variables, for general principles, for universally applicable laws of entrepreneurship that has characterized much of the entrepreneurship literature betrays an impatience with the slow methodical process of description. Attention to careful observation and description is the basis of good scientific research (McKelvey, 1982). In what does all this careful description of new ventures result? A collection of uniquely described ventures, each different from all the others? Once good description is achieved, then good comparisons and contrasts can be made, and subsets of similar ventures can be established. These homogeneous populations are needed before any general rules or theories of new venture creation can be postulated. The lack of such homogeneous samples in the past has led to conflicts in the results of research studies.

The conceptual framework presented here provides a way of analyzing past research studies. Each study can be broken down into the types of individuals, organizations, environments, and processes that were investigated. One way in which the framework can be useful is in identify- 


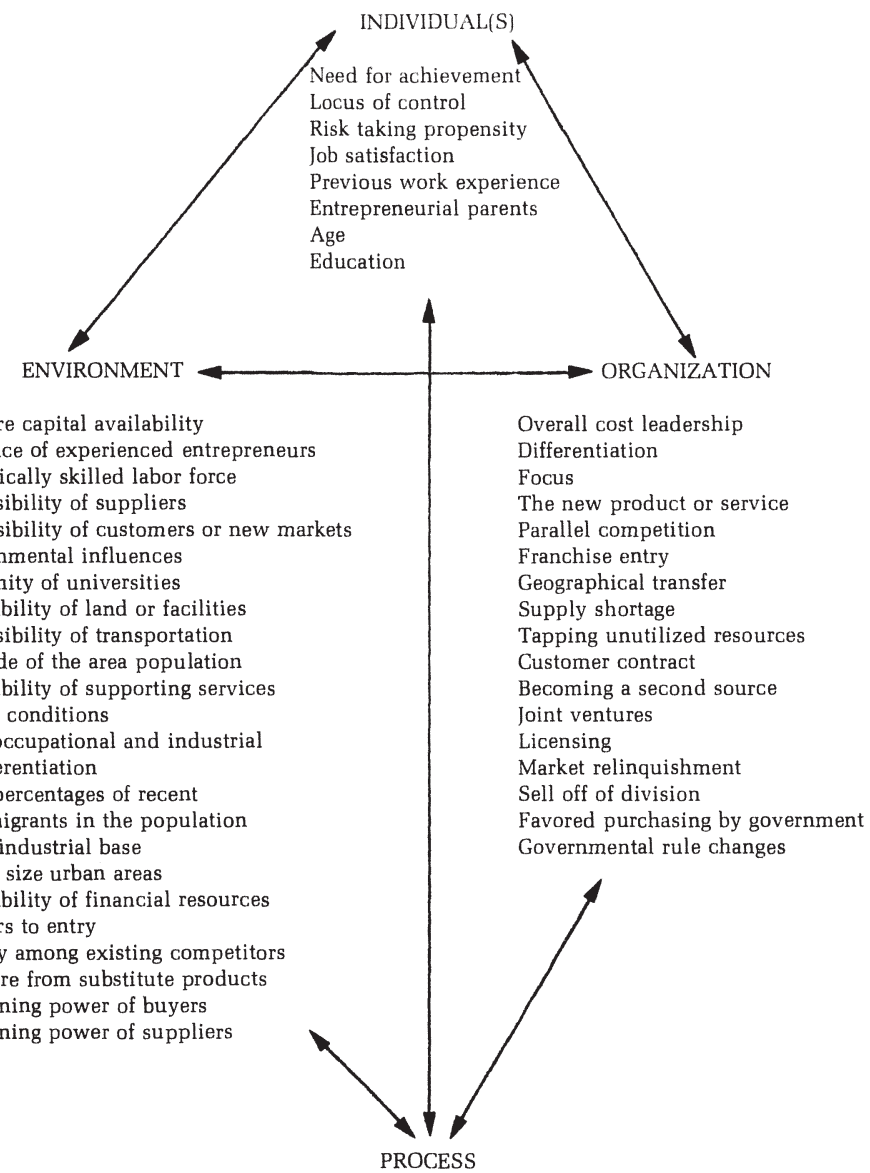

Venture capital availability

Presence of experienced entrepreneurs

Technically skilled labor force

Accessibility of suppliers

Accessibility of customers or new markets

Governmental influences

Proximity of universities

Availability of land or facilities

Accessibility of transportation

Attitude of the area population

Availability of supporting services

Living conditions

High occupational and industrial

differentiation

High percentages of recent

immigrants in the population

Large industrial base

Larger size urban areas

Availability of financial resource

Barriers to entry

Rivalry among existing competitor

Pressure from substitute products

Bargaining power of buyers

Bargaining power of suppliers

PROCESS

Overall cost leadership

ifferentiation

Parallel competition

hise entry

Supply shortage

Tapping unutilized resources

Customer contract

ing a second source

entures

Favored purchasing by government

The entrepreneur locates a business opportunity

The entrepreneur accumulates resources

The entrepreneur markets products and services

The entrepreneur produces the product

The entrepreneur builds an organization

The entrepreneur responds to government and society

Figure 2. Variables in new venture creation. 
ing those aspects of new venture creation neglected by a particular study. New research may then be designed to account for these lacunae. For example, Brockhaus defines his sample of entrepreneurs as:

Individuals who within three months prior to the study had ceased working for their employers and at the time of the study owned as well as managed business ventures. ... The businesses whose owners served as participants were selected from the listing of businesses licensed by St. Louis County, Missouri during the months of August and September, 1975 (1980a, p. 39).

Although Brockhaus, unlike other researchers, attempts to close in on the actual entrepreneurial function by interviewing his entrepreneurs within a few months of the creation of their ventures, useful and necessary distinctions among the individuals and their new ventures are not made. One is not sure what types of firms were studied (retail, service, manufacturing, etc.) or whether the St. Louis environment was likely to influence certain types of individuals to create certain types of firms. Is the process of starting a venture in St. Louis different, or is the process different for certain types of businesses or certain kinds of individuals? Accounting for type of firm, environment, and process in this study would enhance comparison among the individuals in the study and individuals in other studies.

In analyzing results of research studies, a focus on differences in one of the four dimensions might explain conflicting results. For example, studies such as Collins and Moore (1970) suggest that individuals who start firms are social misfits who do not fit into most organizations. Yet other studies such as Cooper (1970) suggest that individuals who start successful firms are good team players. On closer examination it is seen that Collins and Moore studied manufacturing firms that were more like job shops in the 1950s, and Cooper studied high technology firms in the 1960s. High technology industries might require more skills than one individual would be likely to have, necessitating that individuals combine their abilities in teams in order to start an organization successfully.

In addition to providing a means by which past research can be analyzed, the framework outlines a format for future research methodologies and for reporting such research. More careful atten- tion must be paid to the research sample. For example, women entrepreneurs are a popular research topic. If similarities are discovered among women who start firms, are these similarities a result of similar environments? Can differences be attributed solely to psychological or background characteristics? What is the value of research results that are based on such unexamined and possibly heterogeneous sample populations?

Even in a narrowly selected research sample, the framework might be useful in drawing the researcher's attention to considerations inherent in each of the four dimensions, in order that conclusions regarding the virtual sameness of all the members of the sample may not be made too hastily. For example, in a sample of new organizations in the micro-computer industry, a number of considerations might be made. What is the variation among the entrepreneurs in their work backgrounds, education, age? How do competitive strategies used by these new organizations vary? Are there regional or other subenvironments in the industry that cause variations in firms and strategies? What is the variation in the venture creation process: do all individuals devote equal time to financing the organization, hiring personnel, marketing? What differences exist between "new" and "old" firms in this industry?

The brief review of the literature provided earlier is only a running start at a comprehensive analysis and evaluation of the entrepreneurship literature. For example, in a study of individuals who start firms, who are the individuals? Are the individuals in McClelland's samples (McCelland, 1961; McCelland \& Winter, 1969) similar to those in Brockhaus (1980a) or Schrage (1965)? More about the similarities and differences within and among past research samples needs to be known. There are many dimensions and variables across which these samples may be compared.

The framework also points up the importance of interactions of variables among dimensions in understanding new venture creation. How does an individual's background influence the type of activities undertaken to start an organization? Does the marketing individual devote his time to marketing instead of manufacturing, and are there some environments or firms that require more marketing? Is the process of starting a retail store 
similar to that of starting a steel mill? Are entry strategies used by new organizations in the robotics industry similar to those used in the brewery industry?

The framework for describing new venture creation provides the possibility of describing subsets within the unwieldy set of all entrepreneurs and all new ventures. Newly created ventures that display meaningful similarities across the four dimensions could be described and classified together (Gartner, 1982). Significant generalizations regarding some or all new venture creations might emerge, generalizations that do not, however, attempt to mask the variation in new venture creation.

This paper does not purport to answer specific questions about how new ventures are started or provide specific developmental models for new venture creation. No claim is made that the framework or the list of variables is comprehensive; the claim is only that the description of new ventures needs to be more comprehensive than it is at present. A great many more questions are asked here than are answered. However, the paper provides a means of making a fundamental shift in the perspective on entrepreneurship: away from viewing entrepreneurs and their ventures as an unvarying, homogeneous population, and towards a recognition and appreciation of the complexity and variation that abounds in the phenomenon of new venture creation.

\section{References}

Aldrich, H. E. (1979) Organizations and environments. Englewood Cliffs, NJ: Prentice-Hall.

Aldrich, H. E., \& Pfeffer, J. (1976) Environments of organizations. Annual Review of Sociology, 76-105.

Baumol, W. J. (1968) Entrepreneurship in economic theory. American Economic Review, 58(2), 64-71.

Braden, P. (1977) Technological entrepreneurship (Michigan Business Reports, No. 62). Ann Arbor: University of Michigan.

Brockhaus, R. H. (1980a) The effect of job dissatisfaction on the decision to start a business. Journal of Small Business Management, 18(1), 37-43.

Brockhaus, R. H. (1980b) Risk taking propensity of entrepreneurs. Academy of Management Journal, 23, 509-520.

Brockhaus, R. H. (1982) The psychology of the entrepreneur. In C. A. Kent, D. L. Sexton, \& K. H. Vesper (Eds.), Encyclopedia of entrepreneurship (pp. 39-56). Englewood Cliffs NJ: Prentice-Hall.

Brockhaus, R. H., \& Nord, W. R. (1979) An exploration of factors affecting the entrepreneurial decision: Personal characteristics vs. environmental conditions. Proceedings of the National Academy of Management, 364-368.

Bruno, A. V., \& Tyebjee, T. T. (1982) The environment for entrepreneurship. In C. A. Kent, D. L. Sexton, \& K. H. Vesper (Eds.), Encylopedia of entrepreneurship (pp. 288-307). Englewood Cliffs, NJ: Prentice-Hall.

Carland, J. W., Hoy, F., Boulton, W. R., \& Carland, J.A.C. (1984) Differentiating entrepreneurs from small business owners: A conceptualization. Academy of Management Review, 9, 354-359.

Child, J. (1972) Organizational structure, environment and performance: The role of strategic choice. Sociology, 6, 1-22.

Cole, A. H. (1959) Business enterprise in its social setting. Cambridge, MA: Harvard University Press.
Cole, A.H. (1965) An approach to the study of entrepreneurship: A tribute to Edwin F. Gay. In H.G.J. Aitken (Ed.), Explorations in enterprise (pp. 30-44). Cambridge, MA: Harvard University Press.

Collins, O. F., \& Moore, D. G. (1964) The enterprising man East Lansing: Michigan State University.

Collins, O. F., \& Moore, D. G. (1970) The organization makers. New York: Appleton-Century-Crofts.

Cooper, A. C. (1970) The Palo Alto experience. Industrial Research, 12(5), 58-61.

Cooper, A. C. (1979) Strategic management: New ventures and small business. In D. E. Schendel \& C. W. Hofer (Eds.), Strategic management (pp. 316-327). Boston: Little, Brown.

Cooper, A.C., \& Dunkelberg, W. C. (1981) A new look at business entry: Experiences of 1,805 entrepreneurs. In K. H. Vesper (Ed.), Frontiers of entrepreneurship research (pp. 1-20). Wellesley, MA: Babson College.

Daily, C. A. (1971) Entrepreneurial management: Going all out for results. New York: McGraw-Hill.

Danhoff, C. H. (1949) Observations on entrepreneurship in agriculture. In A. H. Cole (Ed.), Change and the entrepreneur (pp. 20-24). Cambridge, MA: Harvard University Press.

DeCarlo, J. F., \& Lyons, P. R. (1979) A comparison of selected personal characteristics of minority and non-minority female entrepreneurs. Journal of Small Business Management, 17(4), 22-29.

Draheim, K. P. (1972) Factors influencing the rate of formation of technical companies. In A. C. Cooper \& J. L. Komives (Eds.), Technical entrepreneurship: A symposium (pp. 327). Milwaukee, WI: Center for Venture Management.

Filley, A. C., \& Aldag, R. J. (1980) Organizational growth and types: Lessons from small institutions. In B. Staw \& L Cummings (Eds.), Research in organizational behavior (Vol. 2, pp. 279-320). Greenwich, CT: JAI Press. 
Gartner, W. B. (1982) An empirical model of the business startup, and eight entrepreneurial archetypes. Unpublished doctoral dissertation, University of Washington, Seattle.

Glueck, W., \& Mescon, T. (1980) Entrepreneurship: A literature analysis of concepts. Paper presented at the annual meeting of the Academy of Management, Detroit, MI,

Gould, L. C. (1969) Juvenile entrepreneurs. American Journal of Sociology, 74, 710-719.

Hannan, M. T., \& Freeman, J. (1977) The population ecology model of organizations. American Journal of Sociology, 82, 929-964

Hartman, C. (1983) Who's running America's fastest growing companies? Inc., 5(8), 41-47.

Hartmann, H. (1959) Managers and entrepreneurs: A useful distinction? Administrative Science Quarterly, 3, 429-457.

Hill, R. (1982) The entrepreneur: An artist masquerading as a businessman? International Management, 37(2), 21-22, 26.

Hornaday, J., \& Aboud, J. (1971) Characteristics of successful entrepreneurs. Personnel Psychology, 24(2), 141-153.

Howell, R. P. (1972) Comparative profiles-Entrepreneurs versus the hired executive: San Francisco Peninsula semiconductor industry. In A. C. Cooper \& J. L. Komives (Eds.), Technical entrepreneurship: A symposium (pp. 47-62). Milwaukee, WI: Center for Venture Management.

Jenks, L. (1965) Approaches to entrepreneurial personality. In H. G. J. Aitken (Ed.), Explorations in enterprise (pp. 8092). Cambridge, MA: Harvard University Press.

Kilby, P. (1971) Hunting the heffalump. In P. Kilby (Ed.), Entrepreneurship and economic development (pp. 1-40). New York: Free Press.

Kimberly, J. R. (1979) Issues in the creation of organizations: Initiation, innovation, and institutionalization. Academy of Management Journal, 22, 437-457.

Komives, J. L. (Ed.). (1969) Karl A. Bostrum seminar in the study of enterprise. Milwaukee, WI: Center for Venture Management.

Komives, J. L. (1972) A preliminary study of the personal values of high technology entrepreneurs. In A. C. Cooper \& J. L. Komives (Eds.), Technical entrepreneurship: A symposium (pp. 231-242). Milwaukee, WI: Center for Venture Management.

Lamont, L. M. (1972) The role of marketing in technical entrepreneurship. In A. C. Cooper \& J. L. Komives (Eds.), Technical entrepreneurship: A symposium (pp. 150-164). Milwaukee, WI: Center for Venture Management.

Leibenstein, H. (1968) Entrepreneurship and development. American Economic Review, 58(2), 72-83.

Liles, P. R. (1974) New business ventures and the entrepreneur. Homewood, IL: Irwin.

Litzinger, W. D. (1965) The motel entrepreneur and the motel manager. Academy of Management Journal, 8, 268-281.

Long, W. (1983) The meaning of entrepreneurship. American Journal of Small Business, 8(2), 47-59.
Maidique, M. A. (1980) Entrepreneurs, champions and technological innovation. Sloan Management Review, 21(2), 59-76.

McCain G., \& Smith, N. (1981, Summer) A contemporary model of entrepreneurial style. Small Business Institute Review, 40-45.

McClelland, D. (1961) The achieving society. Princeton, NJ: Van Nostrand.

McClelland, D., \& Winter, D. G. (1969) Motivating economic achievement. New York: Free Press.

McKelvey, B. (1982) Organizational systematics-Taxonomy, evolution, classification. Berkeley: University of California Press.

Mescon, T., \& Montanari, J. (1981) The personalities of independent and franchise entrepreneurs: An empirical analysis of concepts. Journal of Enterprise Management, 3(2), 149-159.

Mill, J. S. (1848) Principles of political economy with some of their applications to social philosophy. London: J. W. Parker.

Miller, D. (1981) Toward a new contingency approach: The search for organization gestalts. Journal of Management Studies, 18, 1-26.

Palmer, M. (1971) The application of psychological testing to entrepreneurial potential. California Management Review. 13(3), 32-39.

Pennings, J. M. (1980) Environmental influences on the creation process. In J. R. Kimberly \& R. Miles (Eds.). The organization life cycle (pp. 135-160). San Francisco: Jossey Bass.

Pennings, J. M. (1982a) Organizational birth frequencies. Administrative Science Quarterly, 27, 120-144.

Pennings, J. M. (1982b) The urban quality of life and entrepreneurship. Academy of Management Journal, 25, 63-79.

Peters T. J., \& Waterman, R. H. (1982) In search of excellence. New York: Harper \& Row.

Peterson, R. A., \& Berger, D. G. (1971) Entrepreneurship in organizations: Evidence from the popular music industry. Administrative Science Quarterly, 16, 97-107

Pfeffer, J., \& Salancik, G. R. (197\&) The external control of organizations. New York: Harper \& Row.

Porter, M. E. (1980) Competitive strategy: Techniques for analyzing industries and competitors. New York: Fress Press.

Roberts, E. B. (1969) Entrepreneurship and technology. In W Gruber \& D. Marquis (Eds.), Factors in the transfer of technology (pp. 219-237). Cambridge, MA: M.I.T. Press.

Roberts, E. B., \& Wainer, H. A. (1968) New enterprise on Rte 128. Science Journal, 4(12), 78-83.

Schell, D. W., \& Davig, W. (1981) The community infrastructure of entrepreneurship. In K. H. Vesper (Ed.), Frontiers of entrepreneurship research (pp. 563-590). Wellesley. MA: Babson College.

Schrage, H. (1965) The R \& D entrepreneur: Profile of success. Harvard Business Review, 43(6), 56-69. 
Schrier, J. W. (1975) Entrepreneurial characteristics of women. In J. W. Schrier \& J. Susbauer (Eds.), Entrepreneurship and enterprise development: A worldwide perspective (pp. 66 70). Milwaukee, WI: Center for Venture Management.

Schumpeter, J. A. (1934) The theory of economic development (R. Opie, Trans.). Cambridge, MA: Harvard University Press.

Schwartz, E. B. (1976) Entrepreneurship: A new female frontier. Journal of Contemporary Business. 5, 47-76.

Secrest, L. (1975) Texas entrepreneurship. In J. W. Schrier \& J. Susbauer (Eds.), Entrepreneurship and enterprise development: A worldwide perspective (pp. 51-65). Milwaukee, WI: Center for Venture Management.

Shapero, A. (1972) The process of technical company formation in a local area. In A. C. Cooper \& J. L. Komives (Eds.), Technical entrepreneurship: A symposium (pp. 63-95). Milwaukee, WI: Center for Venture Management.

Shapero, A. (1975) The displaced, uncomfortable entrepreneur. Psychology Today, 9(6), 83-88.

Shapero, A., \& Sokol, L. (1982) The social dimensions of entrepreneurship. In C. A. Kent, D. L. Sexton, \& K. H. Vesper (Eds.), Encylclopedia of entrepreneurship (pp. 72-90). Englewood Cliffs, NJ: Prentice-Hall.

Smith, N. (1967) The entrepreneur and his firm: The relationship between type of man and type of company. East Lansing: Michigan State University.

Starbuck, W. H. (1976) Organizations and their environments. In M. Dunnette (Ed.), Handbook of industrial and organizational psychology (pp. 1069-1123). Chicago: Rand McNally.

Stauss, J. H. (1944) The entrepreneur: The firm. Journal of Political Economy, 52(2), 112-127.

Strategic Planning Institute. (1978) The startup data manual. Unpublished manuscript. Cambridge, MA: Strategic Planning Institute.

Susbauer, J. C. (1969) The technical company formation process: A particular aspect of entrepreneurship. Unpublished doctoral dissertation, University of Texas, Austin.

Susbauer, J. C. (1972) The technical entrepreneurship process in Austin, Texas. In A. C. Cooper \& J. L. Komives (Eds.),
Technical entrepreneurship: A symposium (pp. 28-46). Milwaukee, WI: Center for Venture Management.

Thorne, J. R., \& Ball, J. G. (1981) Entrepreneurs and their companies: Smaller industrial firms. In K. H. Vesper (Ed.), Frontiers of entrepreneurship research (pp. 65-83). Wellesley, MA: Babson College.

Timmons, J. A., Smollen, E, \& Dingee, A. L. M. (1977) New venture creation. Homewood, IL: Irwin.

Van de Ven, A. H. (1980) Early planning, implementation and performance of new organizations. In J. R. Kimberly \& R. Miles (Eds.), The organization life cycle (pp. 83-134). San Francisco: Jossey Bass.

Van de Ven, A. H., Hudson, R., \& Schroeder, D. M. (1984) Designing new business startups: Entrepreneurial, organizational, and ecological considerations. Journal of Management, 10(1), 87-107.

Vesper, K. H. (1979) Commentary. In D. E. Schendel \& C. W. Hofer (Eds.), Strategic management (pp. 332-338). Boston: Little, Brown

Vesper, K. H. (1980) New venture strategies. Englewood Cliffs, NJ: Prentice-Hall.

Vesper, K. H. (1981) Scanning the frontier of entrepreneurship research. In K. H. Vesper (Ed.), Frontiers of entrepreneurship research (pp. vii-xiv). Wellesley, MA: Babson College.

Vesper, K. H. (1982a) Expanding entrepreneurship research. In K. H. Vesper (Ed.), Frontiers of entrepreneurship research (pp. vii-xx). Wellesley, MA: Babson College.

Vesper, K. H. (1982b) Introduction and summary of entrepreneurship research. In C. A. Kent, D. L. Sexton, \& K. H. Vesper (Eds.), Encyclopedia of entrepreneurship (pp. xxxixxxviii).

Webster, F. A. (1976) A model for new venture initiation: A disclosure on rapacity and the independent entrepreneur. Academy of Management Review, 1(1), 26-37.

Weick, K. E. (1979) The social psychology of organizing (2nd ed.). Reading, MA: Addison-Wesley.

Williamson, O. E. (1975) Markets and hierarchies, analysis and antitrust implications. New York: Free Press.

William B. Gartner is Assistant Professor of Business and Director of the Center for Entrepreneurship Studies in the School of Business Administration, Georgetown University. 